\title{
Prototype Alat Pengantar Makanan Berbasis Arduino Mega
}

\author{
Diah Aryani $^{1}$; Ignatius Joko Dewanto ${ }^{2}$ Alfiantoro $^{3}$ \\ ${ }^{1}$ Universitas Raharja \\ ${ }^{2}$ STKIP Setiapada Nusantara \\ ${ }^{3}$ Universitas Raharja \\ 1diah.aryani@raharja.info
}

\begin{abstract}
The development of Revolution 4.0 is now bringing change to the culinary business process, making culinary entrepreneurs or restaurant owners challenged to be more creative and innovative to thrive and survive Industrial Revolution 4.0. One of the culinary world business processes in the 4.0 Industrial Revolution is to provide a contemporary service that is one of them is using robots. This study aims to create a prototype Arduino based food Introduction tool Mega is a new breakthrough in the culinary world with the methods of research among other methods of data collection, methods of designing tools and methods of testing tools. So this prototype can be used to deliver food by using RFID (Radio Frequency Identification) based on instructions from Arduino Mega with the command RFID will read the ID on the table and Stepper Motors as a tool drive. So this prototype can be used as a food delivery robot not only as a tool to facilitate the work as well as a tool for the appeal of a restaurant that uses it.
\end{abstract}

Keywords: Arduino Mega, Radio Frequency Identification, Prototype

\section{ABSTRAK}

Perkembangan Revolusi Indutri 4.0 saat ini membawa perubahan juga pada proses bisnis dunia kuliner, sehingga membuat para pengusaha kuliner atau pemilik restoran tertantang untuk lebih kreatif dan inovatif supaya dapat berkembang dan bertahan mengikuti Revolusi Industri 4.0. Salah satu proses bisnis dunia kuliner pada Revolusi Industri 4.0 adalah memberikan layanan layanan yang kekinian yaitu salah satunya adalah menggunakan robot. Pada penelitian ini bertujuan membuat Prototipe Alat Pengantar Makanan Berbasis Arduino mega adalah sebagai terobosan baru dalam dunia kuliner dengan metode penelitian antara lain metode pengumpulan data, metode perancangan alat dan metode pengujian alat. Sehingga prototype ini dapat digunakan untuk mengantar makanan dengan menggunakan RFID (Radio Frequency Identification) berdasarkan instruksi dari Arduino Mega sebagai mikrokontroler, dengan perintah tersebut RFID akan membaca ID yang berada pada meja dan motor Stepper sebagai penggerak alat. Sehingga prototype ini dapat dijadikan sebagai robot pengantar makanan tidak hanya sebagai alat untuk mempermudah pekerjaan juga sebagai alat untuk daya tarik sebuah restoran yang menggunakannya.

Kata kunci: Arduino Mega, Radio Frequency Identification, Prototype 


\section{PENDAHULUAN}

Penerapan revolusi Industri 4.0 pada industri kuliner dalam negeri masih belum diterapkan secara utuh, beberap perusahaan telah menerapkan teknologi industri 4.0 tetapi masih parsial atau belum terintegrasi diseluruh proses inndustri kuliner. Pelayanan pada sebuah restoran memiliki fungsi penting dimana pelayan akan berhadapan langsung dengan para pelanggan. Dengan demikian peranan pelayan sangat berpengaruh sebagai tingkat kepuasan pelanggan dan kualitas restoran tersebut. Sistem pengantaran makanan yang biasa dikirim oleh manusia, ada beberapa masalah apabila masih menggunakan sumber daya manusia karena terdapat kekurangan yaitu manusia bisa absen masuk kerja yang dikarenakan sakit atau masalah lainnya. Dan lainnya adalah masalah pembiyayaan manusia masih terlalu mahal karena mengikuti aturan pemerintah atau UMR (Upah Minimum Regional).

Sebuah robotika dibuat memiliki fungsi untuk mempermudah sesuatu pekerjaan, media pembelajaran, atau hanya sebagai media permainan. Sebagai contoh robot pramusaji yang saat ini banyak berkembang di negara-negara maju. Robot pengantar makanan tidak hanya sebagai alat untuk mempermudah pekerjaan juga sebagai alat untuk daya tarik sebuah restoran yang menggunakannya.

Penelitian sebelumnya dilakukan oleh Himawan Setiadi [1] dari Telkom University berjudul "Perancangan Prototipe Robot Pengantar Makanan di Restoran Cepat Saji berbasis Mikrokontroler". Merupakan prototype robot beroda yang mengantar makanan dengan dukungan mikrokontroler dapat mengantar makanan ke pelanggan di restoran cepat saji [1].

Selanjutnya Penelitian yang dilakukan Dwi Budi Susilo, dkk [2] pada Jurnal Teknik Elektro Universitas Negeri Semarang, dengan judul "Prototype Mesin Pengantar Barang Otomatis Menggunakan Load Cell Berbasis Robot Line Follower", Menciptakan robot dapat mengantar makanan dengan dukungan line follower dengan pengendalian telpon sellular [2]

Selain itu penelitian yang dilakukan oleh Asep Saefullah, Endang Sunandar, Muhammad Nur Rifai dari Journal CCIT, STMIK Raharja, Tangerang, Indonesia. Dengan judul "Prototipe Robot Pengantar Makanan Berbasis Arduino Mega Dengan Interface Web Browser". Pada penelitian ini bertujuan untuk dapat membantu penjual makanan mengantarkan makanan, robot yang dirancang memiliki tempat yang berguna untuk meletakkan makanan dan memiliki user interface berupa web browser yang berguna untuk mengendalikan robot.[3]

Dalam penjelasan diatas mengenai alat pengantar makanan baik berbasis Mikrokontroler, Telpon Selular dan Arduino Mega ini, dapat dirumuskan permasalahan yaitu bagaimana cara alat dapat berjalan untuk pengantara maknanan, bagaimana cara alat dapat mengetahui meja pelanggan yang memesan makanan. Sehingga penelitian ini bertujuan membuat Prototipe Alat Pengantar Makanan Berbasis Arduino mega adalah sebagai terobosan baru dalam dunia kuliner dengan merancang prototype yang dapat digunakan untuk mengantar makanan dengan menggunakan RFID ( Radio Frequency Identification) berdasarkan instruksi dari Arduino Mega sebagai mikrokontroler, dengan perintah tersebut RFID.

\subsection{Arduino Mega}

Herri dkk, [4] mengatakan bahwa Arduino Mega adalah board mikrokontroler berbasias ATMega2560. Modul ini memiliki 54 digital input/output dimana 14 digunakan untuk PMW output dan 16 digunakan sebagai analog input, 4 untuk UART, $16 \mathrm{MHz}$ osilator kristal,koneksi USB, power jack, ICSP Header dan tombol reset [4]. Modul ini memiliki segalanya yang dibutuhkan untuk memprogram mikrokontrolerseperti kabel USB dan sumber daya melalui adaptor ataupun battery.

Aji Nuryaman, dkk [5] Arduino Mega 2560 adalah papan pengembangan mikrokontroller yang berbasis Arduino dengan menggunakan chip ATmega2560 [5]. Board ini memiliki pin I/O yang 
cukup banyak, sejumlah 54 buah digital I/O pin (15 pin diantaranya adalah PWM), 16 pin analog input, 4 pin UART (serial port hardware). Arduino Mega 2560 dilengkapi dengan sebuah oscillator $16 \mathrm{Mhz}$, sebuah port USB, power jack DC, ICSP header, dan tombol reset. Board ini sudah sangat lengkap, sudah memiliki segala sesuatu yang dibuthkan untuk sebuah mikrokontroller. Dengan penggunaan yang cukup sederhana, anda tinggal menghubungkan power dari USB ke PC anda atau melalui adaptor AC/DC ke jack DC. Pemrograman board Arduino Mega 2560 dilakukan dengan menggunakan Arduino Software (IDE). Chip Atmega2560 yang terdapat pada Arduino Mega 2560 telah diisi program awal yang sering disebut bootloader. Bootloader tersebut yang bertugas untuk memudahkan anda melakukan pemrograman lebih sederhana menggunakan Arduino Software, tanpa harus menggunakan tambahan hardware lain.

\subsection{Radio Frequency Identification}

Menurut Mulyanto [6] RFID adalah istilah umum teknologi yang menggunakan teknologi gelombang radio untuk secara otomatis mengidentifikasi orang atau benda [6]. Ada beberapa metode identifikasi, tetapi yang paling umum adalah untuk menyimpan nomor seri yang mengidentifikasi orang atau benda, dan mungkin informasi lainnya, pada microchip yang terpasang pada antena (chip dan antena bersama-sama disebut transporder RFID atau tag RFID. Antena memungkinkan chip untuk mengirimkan informasi identifikasi untuk pembaca. Pembaca mengubah gelombang radio yang dipantulkan kembali dari tag RFID menjadi informasi digital yang kemudian dapat diteruskan ke komputer yang dapat memanfaatkannya.

\section{METODE/PERANCANGAN PENELITIAN}

\subsection{Metode Pengumpulan Data}

Pada tahapan ini dilakukan pengumpulan data dengan wawancara dan studi kepustakaan. Wawancara dilakukan dengan pihak pemilik restoran untuk mengetahui kebutuhan penunjang operasional yang sedang berjalan di restoran ini. Khususnya terkait dengan pelayanan yang sudah berjalan serta yang akan dilakukan dengan pemanfaatan teknologi industri 4.0 sedangkan studi kepustakaan dilakukan dengan cara mengumpulkan informasi melalui sumber buku dan tulisan terkait dengan Arduino maupun laporan KKP yang terdahulu sebagai referensi. Sumber-sumber lain y mendukung penelitian ini di peroleh melalui internet seperti penelitian-penelitian dan jurnal-jurnal yang telah ada.

\subsection{Metode Perancangan}

\section{a. Metode Perancangan Sistem}

Pada tahap ini dilakukan perancangan alat Pengantar Makanan pada Bukit Pelayangan Resto dengan menggunakan Flowchart. Sutanto P, dkk (2017), menjelaskan bahwa "Flowchart adalah suatu teknik analisa yang digunakan untuk mendeskripsikan bebrapa aspek dari sistem informasi dalam pola yang jelas, logikal dan ringkas. Keuntungan dari peng-gunaan flowchart adalah representasi dalam bentuk gambar lebih mudah dipahami dan membuat lebih mudah dalam me -nyimpan suatu data interview serta dapat dengan mudah dan cepat untuk direvisi" [7]. Berikut adalah gambaran flowchart sistem prototype yang diusulkan pada Bukit Pelayangan Resto. 


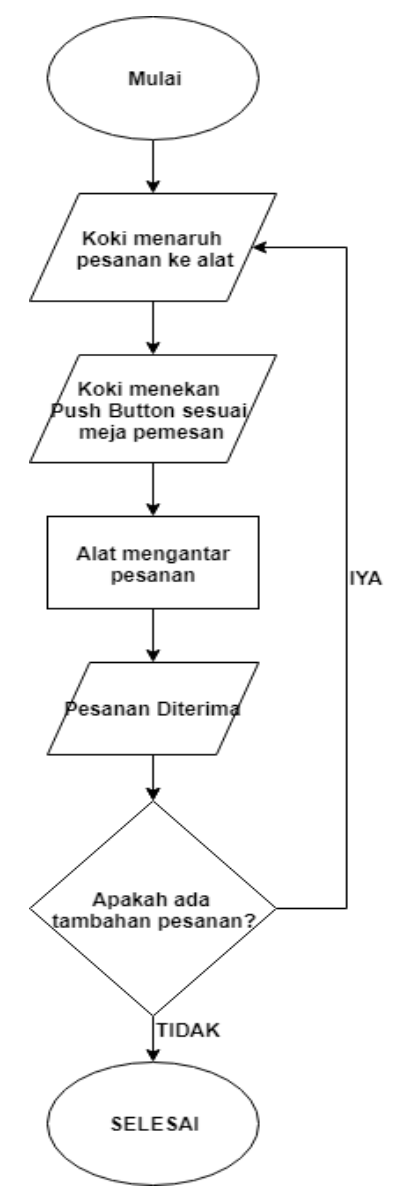

Gambar 1. Flowchart Sistem Usulan Keseluruhan

Berikut adalah penjelasan flowchart sistem yang diajukan:

1. 2 (dua) simbol terminal, yang berperan sebagai "Mulai" dan "Selesai" pada aliran proses flowchart sistem penyampaian informasi yang berjalan.

2. 3 (tiga) simbol input/ output, menyatakan proses input/ output: yaitu pesanan ditaruh di alat dan diberikan perintah untuk menuju meja.

3. 1 (satu) simbol proses, yaitu alat mulai bergerak untuk melakukan pengantaran pesanan.

4. 1 (satu) simbol decision, yang menunjukan sebuah langkah untuk mengambil keputusan jika "iya" atau "tidak", yaitu apakah ada pesanan tambahan dari meja yang sama.

\section{b. Metode Perancangan Alat}

Pada perancangan prototype alat pengantar makanan yang penulis rancang ini meliputi perangkat keras (hardware) dan perangkat lunak (software). Guna menghasilkan sistem yang baik untuk mensinkronisasikan perangkat keras dan perangkat lunak protitpe alat pengantar makanan pada Bukit Pelayangan Resto. Adapun beberapa bahan-bahan yang digunakan sebagai berikut:

\section{Perangkat Keras (Hardware):}

Perancanan Prototype Alat Pengantar Makanan pada Bukit Pelayangan Resto dirancang agar alat dapat berfungsi sebagai alat pengantar makanan yang menggunakan motor stepper sebagai penggerak alat yang dikontrol oleh Arduino Mega. Alat juga dilengkapi dengan RFID Reader sebagai alat pembaca meja tujuan, dimana apabila RFID 
Reader membaca meja yang dituju yang sudah diberikan ID menggunakan RFID Tag/ Card maka alat akan berhenti secara otomatis dijelaskan pada Diagram Sistem berikut:

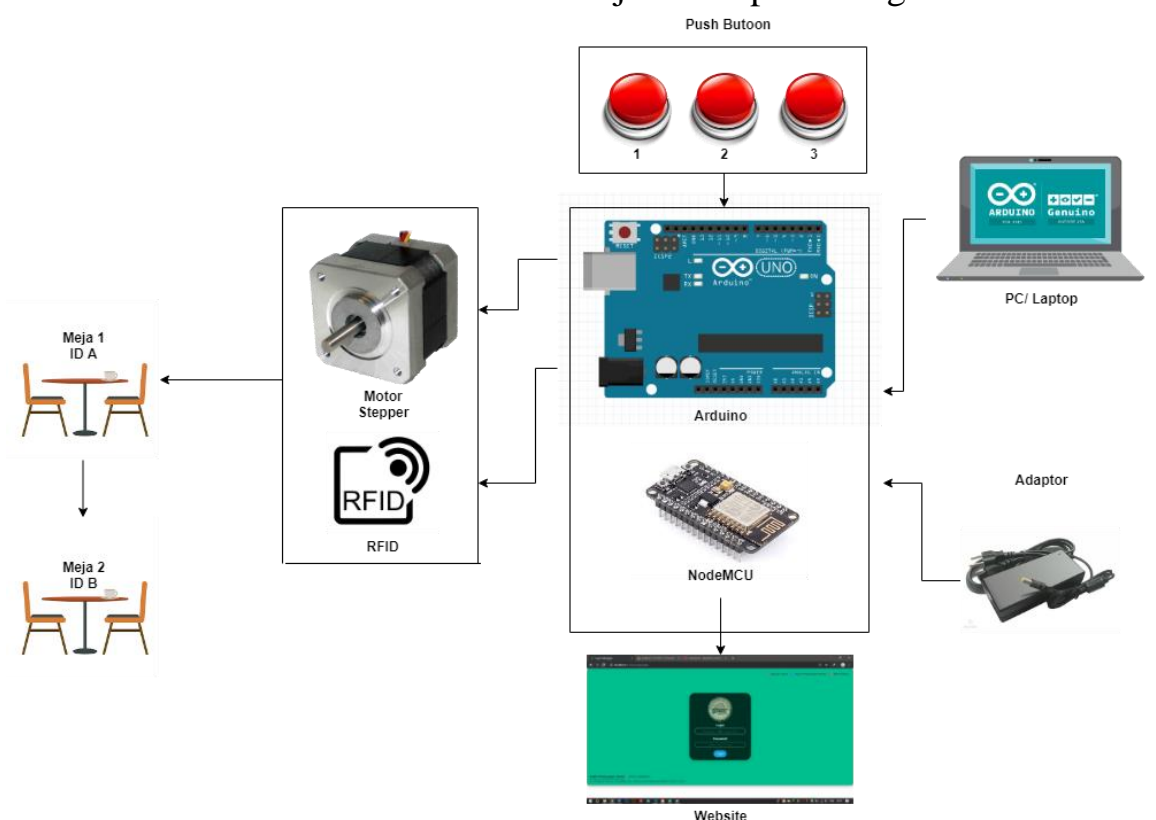

Gambar 2. Diagram Gambar Sistem Yang Diusulkan

Keterangan:

1. PC/ Laptop sebagai listing program yang akan diinput pada Arduino dan NodeMcu.

2. Adaptor sebagai power untuk Arduino dan NodeMcu.

3. Arduino sebagai mikrokontroler yang akan memberi perintah pada komponen lainnya seperti push button, motor stepper, RFID reader.

4. Push button sebagai komponen yang memberi perintah motor stepper untuk pengiriman dan alat untuk kembali ketempat awal (push button 1 untuk meja 1, push button 2 untuk meja 2, push button 3 untuk kembali ke tempat awal).

5. Motor stepper sebagai penggerak alat menuju meja pelanggan.

6. RFID reader sebagai pembaca ID pada meja pelanggan dan memberitahu kembali ke Arduino untuk menghentikan gerak motor stepper.

7. RFID tag/ card berisikan ID untuk pembeda dan ditempatkan pada setiap meja pelanggan yang nantinya akan dibaca oleh RFID reader.

8. NodeMcu sebagai mikrokontroler untuk mengirim data pada website.

9. Website sebagai penampil data.

\section{Perangkat Lunak (Software):}

Sistem perangkat lunak yang dimaksud adalah Arduino IDE yang merupakan perangkat lunak untuk menuliskan listing program Arduino Uno, sehingga sistem A rduino Uno yang sudah dibuat dapat bekerja sesuai dengan apa yang diinginkan. Pada perancangan perangkat lunak Arduino Uno ini menggunakan bahasa pemrograman $\mathrm{C}$ yang dimana listing programnya dapat di compile dan upload langsung kedalam Arduino Uno menggunakan Arduino IDE, adapun tampilan jendela Arduino IDE pada saat menuliskan listing program seperti berikut: 


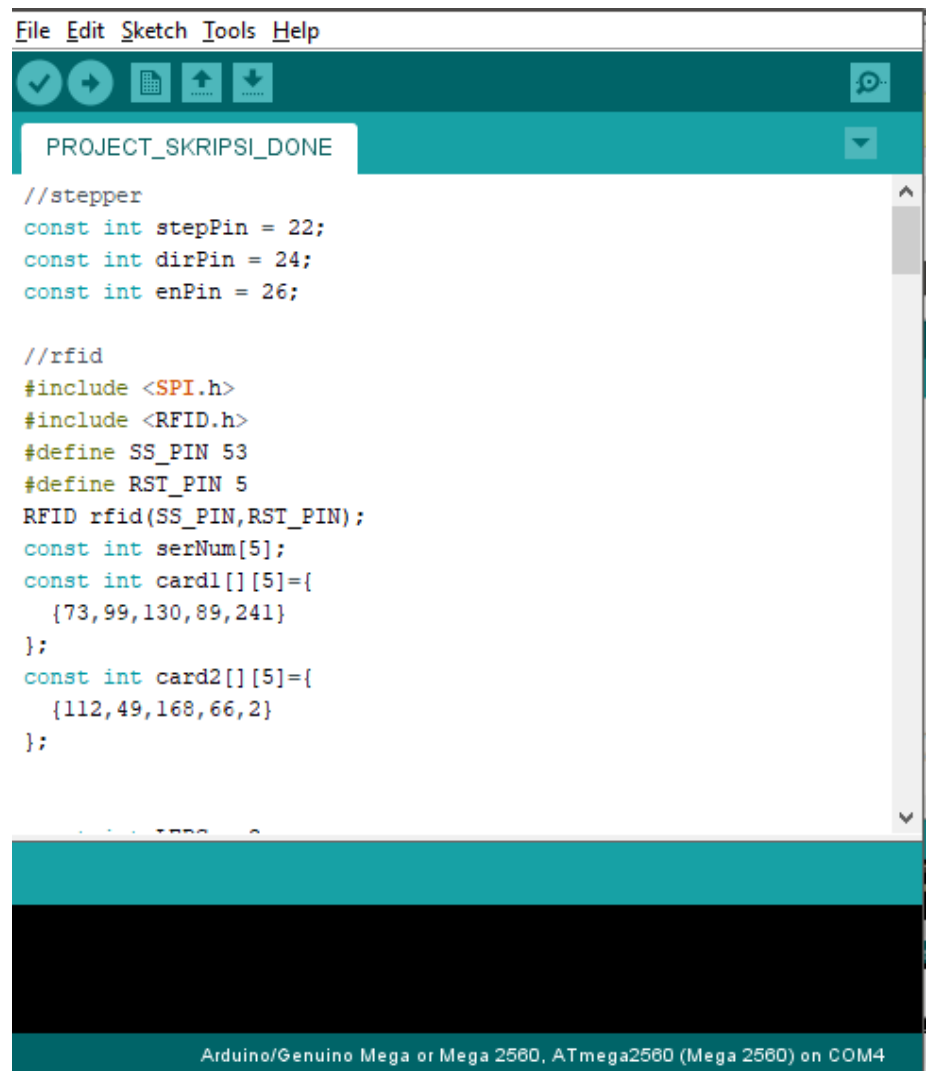

Gambar 3. Tampilan Listing Program Arduino IDE

Adapun tahap yang akan dilakukan adalah menuliskan listing program (Compile) mengecek apakah ada kesalahan dalam listing program yang ditulis (Upload) mengupload listing program ke dalam Arduino Mega dan NodeMcu ke Arduino IDE. Adapun langkahlangkahnya dapat kita di lihat sebagai berikut:

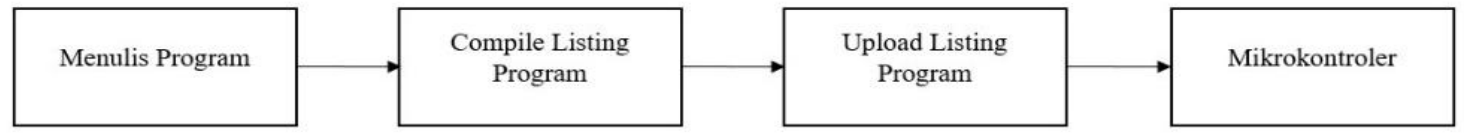

Gambar 4. Upload Listing Program Ke Dalam Arduino Mega

\subsection{Metode Pengujian Alat}

Pada tahap testing dilakukan pengujian terhadap sistem yang dibuat yaitu dengan menggunakan metode BlackBox testing, adapun pengujian dilakukan melalui interface Arduino IDE, dimana pengujian tersebut agar dapat mengetahui fungsionalitas dari suatu interface yang dirancang, adapun tahapannya tersebut untuk menemukan kesalahan dalam beberapa kategori, diantaranya adalah sebagai berikut:

1. Dengan memperhatikan fungsi-fungsi yang digunakan, seperti fungsi untuk berkomunikasi dengan piranti lain dengan memperhatikan fungsionalitasnya.

2. Memperhatikan kesalahan-kesalahan yang dapat terjadi ketika melakukan debug ataupun running program.

3. Dengan memperhatikan struktur performa sehingga aplikasi dapat digunakan dengan baik dan mendukung sistem yang dibuat. 
4. Dengan memperhatikan kesalahan-kesalahan inisialisasi fungsi yang digunakan dalam berinteraksi dengan piranti lain.

Pengujian dengan metode BlackBox sangat memperhatikan pada fungsi fungsional dari suatu program dengan melakukan pendekatan yang melengkapi untuk menemuka kesalahan atau error.

\section{HASIL DAN PEMBAHASAN}

\subsection{Hasil Pengujian RFID (Radio-frequency identification)}

Pada uji coba kali ini adalah pengujian RFID dengan Arduino Mega, modul tersebut berjalan sesuai dengan sebagai mana mestinya pada Prototype Alat Pengantar Makanan Pada Bukit Pelayangan Resto dengan 1 buah Mikrokontroler Arduino Mega yang memiliki 54 buah pin digital (15 diantaranya pin PWM output) pada boardnya. Pada RFID memiliki 8 buah pin diantaranya pin SDA, SCK, Mosi, Miso, Rq, GND, RST, 3.3V. Pin 3.3V pada RFID dihubungkan pada pin 3.3V pada Arduino Mega, pin GND dihubungkan dengan pin GND pada Arduino Mega, pin RST, SDA, SCK, Mosi, Miso pada RFID dihubungkan pada pin D5, D53, D52, D50, dan D51 pada Arduino Mega.

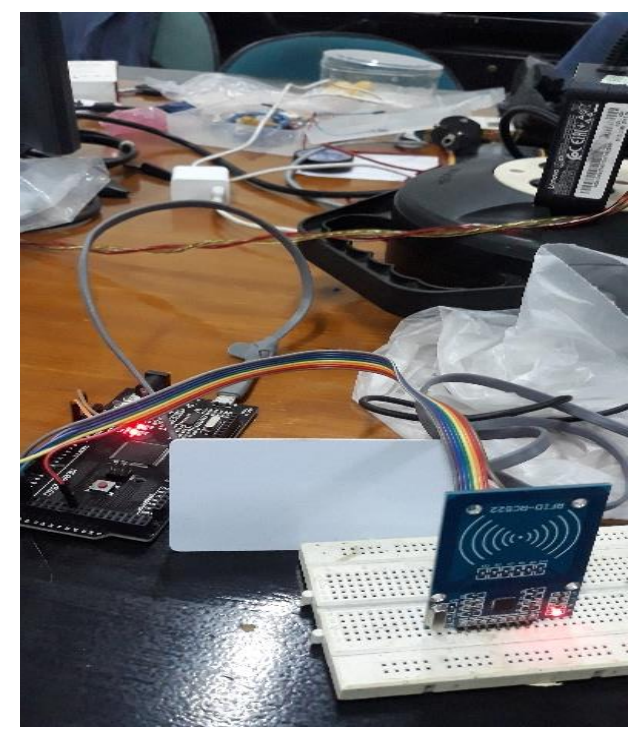

Gambar 5. Hasil Pengujian RFID (Radio-frequency identification)

Pengujian Arduino Mega Pada Modul Driver TB6560 Dengan Motor Stepper dan Push Button

Pada uji coba ini adalah pengujian cara kerja Arduino Mega pada modul driver tb6560 dengan motor stepper dan push button ini apakah motor stepper ini berjalan sebagaimana mestinya. Apabila push button ditekan maka motor stepper akan mulai berjalan sesuai ke meja pelanggan. Motor stepper terhubung pada modul driver tb6560 pada coil A yaitu (A+,A-), Coil B yaitu (B+, B-). Catu daya pada tb6560 untuk mengerakan motor stepper adalah 12V-400Ma dan 1 step gerak motor stepper adalah 3,7 Kg dari 200 step keseluruhan, kemudian modul driver dihubungkan dengan Arduino Mega seperti (VCC) di pin 5v dan GRD ke GRD, (CLK+) di pin (22), (CW+) di pin ( 24 ) dan (EN+) di pin ( 26) untuk push button di pin $(32,38,42)$ semua input ini terhubung pada mikrokontroller Arduino Mega. 


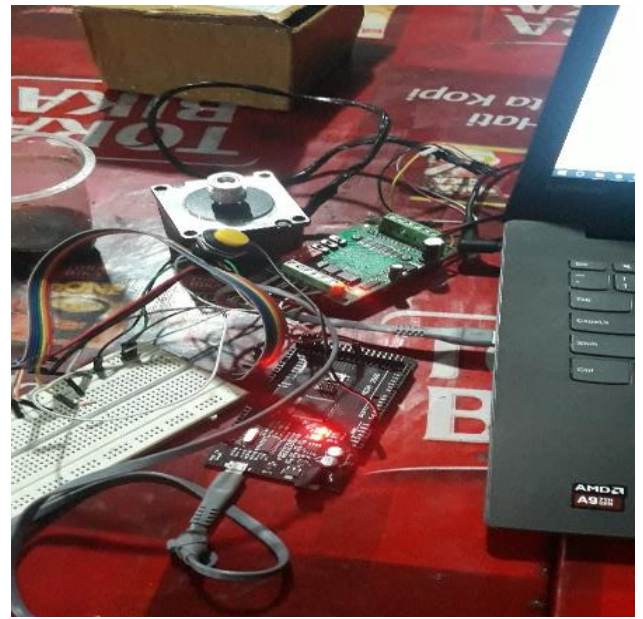

Gambar 6. Hasil Pengujian Modul Driver Dengan Motor Stepper Dan Push Button

Berdasarkan hasil pengujian diatas maka pada penelitian ini memberikan perbedaan pada penelitian sebelumnya yang dilakukan oleh Asep Saefullah, Endang Sunandar, Muhammad Nur Rifai dari Journal CCIT, STMIK Raharja, Tangerang, Indonesia. Dengan judul "Prototipe Robot Pengantar Makanan Berbasis Arduino Mega Dengan Interface Web Browser"[1]. Pada penelitian ini Prototype Alat Pengantar Makanan Berbasis Arduino Mega yang merupakan terobosan baru dalam dunia kuliner yaitu Prototipe Alat Pengantar Makanan Berbasis Arduino mega adalah perancang prototype yang dapat digunakan untuk mengantar makanan dengan menggunakan RFID ( Radio Frequency Identification) berdasarkan instruksi dari Arduino Mega sebagai mikrokontroler, dengan perintah tersebut RFID. Penambahan RFID serta motor stepper sebagai penggerak alat menuju meja pelanggan dengan menggunakan rel untuk lalu lintas Protype tersebut adalah hal yang menjadi pembeda pada penelitian dilakukan oleh Asep Saefullah, Endang Sunandar, Muhammad Nur Rifai (2017) dari Journal CCIT, STMIK Raharja, Tangerang, Indonesia.

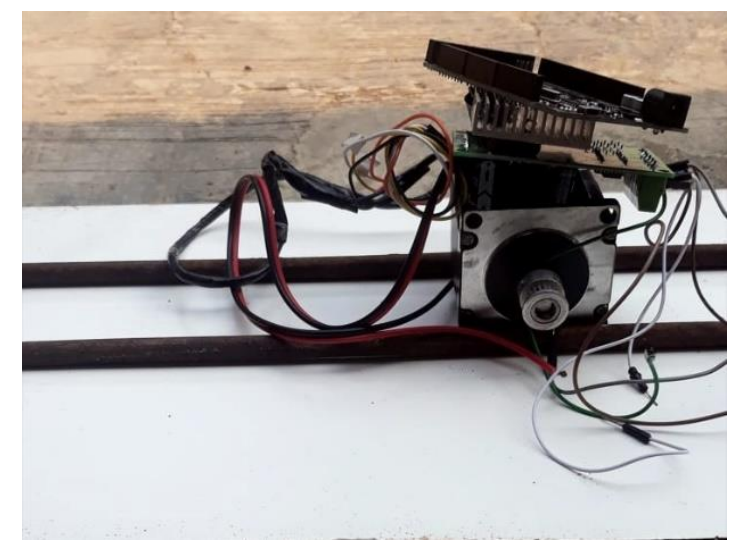

Gambar 7. Rancangan Prototype Alat Pada Rel

\section{KESIMPULAN DAN SARAN}

Setelah melaksanakan penelitian dan mencoba memecahkan masalah yang ada, maka mendapatkan kesimpulan yaitu perancangan alat pengantar makanan sesuai dengan meja pelanggan yang memesan makanan dengan cara menggunakan beberapa push button yang diberikan perintah sesuai dengan ID meja pada pelanggan dan motor stepper akan bergerak secara otomatis menuju meja pelanggan. dengan cara menggunakan RFID reader yang ditempatkan pada alat akan membuat 
Motor Stepper berhenti secara otomatis ketika RFID reader membaca sebuah ID yang dipanggil dan sama pada RFID tag/card yang ditempatkan pada meja pelanggan.

Dari perancangan alat yang dilakukan serta proses tahapan uji coba maka dapat disarankan untuk penelitian selanjtnya yaitu dengan menambahkan beberapa fungsi alat antara lain

Dengan ditambahkan modul mp3 player agar alat dapat mengeluarkan suara untuk berinteraksi kepada pelanggan dan dapat ditambahkan sensor ultrasonic sebagai komponen yang dapat mendeteksi objek dan membuat alat berhenti sejenak sampai objek didepannya sudah tidak ada.

\section{UCAPAN TERIMAKASIH}

Saya dan tim penulis lainnya mengucapkan terima kasih kepada Universitas Raharja yang telah memberikan dukungan dalam pelaksanaan dan penyelesaian penulisan jurnal ini, semoga penulisan ini dapat bermanfaat dan dapat dikembangkan pada penelitian selanjutnya.

\section{DAFTAR PUSTAKA}

Kutipan berturut-turut dalam tanda kurung [1]. Kalimat tanda baca berikut braket [2]. Merujuk hanya untuk nomor referensi, seperti pada [3] -Jangan menggunakan "Ref. [3] "atau" referensi [3]. Minimal daftar pustaka sebanyak 5 Kutipan.

[1] Himawan Setiadi, Perancangan Prototipe Robot Pengantar Makanan di Restoran Cepat Saji berbasis Mikrokontroler", Jurnal Telkom University, 2017

[2] Dwi Budi Susilo, dkk. 2018). Prototype Mesin Pengantar Barang Otomatis Menggunakan Load Cell Berbasis Robot Line Follower. Jurnal Teknik Elektro Universitas Negeri Semarang, Vol 10. No. 1.2018,

[3] Asep Saefullah, dkk. 2017. Prototipe Robot Pengantar Makanan Berbasis Arduino Mega Dengan Interface Web Browser Pada CCIT Journal, 10(2), 269-279, Vol.10 No.2-Agustus 2017

[4] Herri Trisna Frianto, dkk. 2016. Absensi Mahasiswa Menggunakan Sensor Rfid Dan Mikrokontroller Arduino Atmega 2560 Untuk Perhitungan Kompensasi Kehadiran Dan Penilaian Pada Jurnal Riset Komputer (JURIKOM), Volume : 3, Nomor: 1, Februari 2016

[5] Aji Nuryaman, dkk. Rancang Bangun Prototipe Alat Pengukur Kecepatan Kendaraan Dengan Sensor Infra Merah Pada Prosiding - Seminar Nasional Teknik Elektro UIN Sunan Gunung Djati Bandung, pp. 345-366, Jan. 2018

[6] Ali Mulyanto, Yulius Beny Kushermanto. 2017. Penerapan Teknologi RFID Modul RC522 Berbasis Raspberry Pi B+ Pada Sistem Absensi Siswa di SMK At-Taqwa Cabangbungin Kabupaten Bekasi Pada Jurnal Informatika SIMANTIK Vol.1 No.2 Maret 2017

[7] Peter Sutanto, Alexander Setiawan, Djoni Haryadi Setiabudi. Perancangan Sistem Forecasting di Perusahaan Kayu UD. 3G dengan Metode ARIMA Pada Jurnal INFRA Vol.5 No.1 2017 